\title{
Virtual Reality as a Tool for Public Consultations in Spatial Planning and Management
}

\author{
Agnieszka Szczepańska ${ }^{1, *(D)}$, Rafał Kaźmierczak ${ }^{2}$ (D) and Monika Myszkowska ${ }^{3}$ \\ 1 Department of Socio-Economic Geography, Institute of Spatial Management and Geography, Faculty of \\ Geoengineering, University of Warmia and Mazury in Olsztyn, 10-724 Olsztyn, Poland \\ 2 Department of Spatial Analysis and Real Estate Market, Institute of Spatial Management and Geography, \\ Faculty of Geoengineering, University of Warmia and Mazury in Olsztyn, 10-724 Olsztyn, Poland; \\ rafal.kazmierczak@uwm.edu.pl \\ 3 Scientific Circle of Spatial Management, Institute of Spatial Management and Geography, Faculty of \\ Geoengineering, University of Warmia and Mazury in Olsztyn, 10-724 Olsztyn, Poland; \\ monika.myszkowska@student.uwm.edu.pl \\ * Correspondence: aszczep@uwm.edu.pl
}

Citation: Szczepańska, A.;

Kaźmierczak, R.; Myszkowska, M. Virtual Reality as a Tool for Public Consultations in Spatial Planning and Management. Energies 2021, 14, 6046. https://doi.org/10.3390/en14196046

Academic Editor: Svetlana Gutman

Received: 7 August 2021

Accepted: 21 September 2021

Published: 23 September 2021

Publisher's Note: MDPI stays neutral with regard to jurisdictional claims in published maps and institutional affiliations.

Copyright: (c) 2021 by the authors. Licensee MDPI, Basel, Switzerland. This article is an open access article distributed under the terms and conditions of the Creative Commons Attribution (CC BY) license (https:// creativecommons.org/licenses/by/ $4.0 /)$.

\begin{abstract}
Planning and management of urban space that involves the local community the process is key to optimal management of the surroundings, in line with social needs. Social isolation imposed because of the COVID-19 pandemic considerably reduces the possibility of conducting public consultations. This study hypothesized that such consultations can be carried out using new visualisation technologies in the virtual reality (VR) area. Owing to the development of new technologies, innovative services can be created which make it easier for recipients to absorb new content. To this end, the ArchitektVR application was developed, which uses enhanced reality for public consultations concerning planned land development. 3D visualisation with VR enables the presentation of various aspects of area development in a clear form, understandable to an average user with no specialist qualifications. It facilitates the presentation and creation of multiple variants/scenarios for the future shape of the area. The research assumptions were tested for a disused area of a water body. According to preliminary tests, the use of virtual reality could provide a new form of communication between decision-makers and citizens. Effective and easy-to-understand visualisations might provide encouragement to participate in local matters and enable citizens to make better decisions. 3D visualisation enabled concerned individuals to assess the potential development of a selected area fragment without an in-person visit, either in the field or to an office. This is of particular importance in relation to the COVID-19 pandemic and sanitary restrictions.
\end{abstract}

Keywords: virtual reality; public consultations; spatial planning; urban design

\section{Introduction}

Contemporary urban planning and management require the local community to participate actively in the development of its surroundings. This is consistent with urban planning documents such as the Leipzig Charter on Sustainable European Cities [1] and the New Athens Charter [2]. These documents emphasize the need to create new systems of participation and to increase the involvement of citizens and various groups of city dwellers in local decision-making processes. Most authors claim that open space within a city is among the most important elements of the city's spatial structure and social system. According to the Leipzig Charter on Sustainable European Cities, the creation and development of high-quality integrated spaces is among the main tasks pursued by the state, local authorities, business entities and citizens. This arises from the fact that cities and their elements are not built for an individual but a community [3], and the spaces best adapted to life are those which are co-developed by the community, i.e., the residents themselves. Management of urban space is achieved through the activities of 
local administration bodies, investors and space users, but a significant role in the process can also be played by the local community, which consists of its everyday users. The ability to reach out to and collaborate with the local community is key to optimal land development in line with social needs. Participating in spatial management decisions creates a feedback loop - the better a space is suited to the residents' needs, the higher the degree of participation; the higher the degree of participation, the better a space suits the residents' needs [4]. In this regard, social participation in spatial management is particularly important [5].

The importance of social participation for local development is strongly emphasized in strategic documents on the development and future of Polish towns and cities. They include the National Urban Policy 2023, which states: "Residents' involvement in various areas of city life is becoming increasingly common in Poland. This arises from the residents' need to be active subjects participating in city development planning and management". According to the assumptions of this strategic document, cities' activities aimed at propagating public participation must contribute to:

- improving cooperation between all city actors, building civil society, developing local communities, and increasing mutual trust in society and care for the common good; - increasing residents' identification with a place and sense of responsibility for the surroundings and the local community, and increasing the development potential of an area through better planning of its development.

Residents should participate in the planning and decision-making process to the greatest extent possible. Mutual understanding can be reached by social dialogue between local city authorities and the residents. This builds a sense of the possibility for the local community to influence the method and directions of area development. The social dialogue can have different forms. Regarding urban space, its main form involves public consultations on land development methods, architectural forms, style and the function of the land, etc.

Social isolation imposed because of the COVID-19 pandemic considerably reduced the possibility of conducting public consultations. The restrictions imposed by the authorities prevent group meetings which would be used to exchange opinions, views and suggestions regarding planning the development of particular areas. Therefore, the question of how to conduct public consultations during prolonged social isolation was posed. This study hypothesizes that this problem can be solved by new VR visualisation technologies, whose observable result in the form of a 3D image requires from the user the least amount of specialist knowledge related to perception, spatial imagination, interpretation, etc. The objective of the study was to develop a tool for conducting public consultations for land development with virtual reality (VR) and to test it using a selected area. The testing area was a post-excavation water body formed at a site of earlier aggregate excavation. The water body is situated in Suwałki, in northeastern Poland.

\section{Literature Review}

\subsection{Social Participation}

Social participation occurs when a local community taking part in city life makes joint decisions with the local government aimed at solving problems related to living space. It enables members of the local community to express their opinions and share their experiences. This participation takes the form of social dialogue, which is understood to denote the process of interaction between various participants (authorities and citizens) aimed at reaching a compromise in specific matters. Its specific form is civic dialogue, in which citizens express their opinions on matters which are important to them, whereby they can have a tangible influence on decisions made by authorities, including local governments. Such dialogue is regarded as a tool for strengthening citizens' role in public discussions [6]. The main form of social dialogue is teamwork between local communities and local government representatives [7], which can result in agreement on decisions regarding the community members' place of residence. 
Social participation is defined as the direct and indirect, formalized and non-formalized, and individual and collective participation of citizens in reaching and executing decisions concerning the common good [8]. Lauriusz [9] points out that authorities execute projects using a quantitative and technical approach, whereas residents perceive the space that surrounds them qualitatively-they pay attention to non-quantifiable aspects (residents identify problems differently and assign different ranks to them). This is why social participation is so important for space management in line with local community needs.

Civic participation includes involving citizens in measures initiated and controlled by the authorities [7]. These measures are implemented through active participation tools, which allow local authorities to receive information about the assessment of, opinions on or level of acceptance for a specific action. Such measures include acquiring information directly (e.g., through questionnaires), at meetings and discussions (e.g., public consultations, public debates, diagnostic and project-related workshops), and through permanent discussion groups (e.g., local community forums, Internet forums and periodic meetings) [9]. Public consultations, which are one of the forms of social dialogue and are a manifestation of participation in decision-making and involvement of residents in the development and transformation of local space, are central to this study. Public consultations bring many tangible benefits, as projects planned for urban space can be better suited to the residents' needs and expectations.

It should also be emphasized that city authorities need to choose the channels and methods of communication with the residents that are appropriate for the subject and the recipients. The main forms, tools and instruments of public participation identified in the National Urban Policy 2023 are shown in Figure 1.

\begin{tabular}{|c|c|}
\hline participatory budgets & $\begin{array}{l}\text { - one of the most advanced and and increasingly } \\
\text { popular methods to ensure residents' } \\
\text { participation in matters related to city } \\
\text { development }\end{array}$ \\
\hline $\begin{array}{l}\text { information and } \\
\text { communication tools }\end{array}$ & $\begin{array}{l}\text { - streamline the process by involving a wide range } \\
\text { of those concerned and providing a rapid } \\
\text { communication form }\end{array}$ \\
\hline working meetings & $\begin{array}{l}\text { - a form of developing public interest in the city } \\
\text { development policy, seeking opinions and } \\
\text { gathering information }\end{array}$ \\
\hline surveys & $\begin{array}{l}\text {-involve gathering and analysing citizens' } \\
\text { opinions based on their perception and } \\
\text { assessment of local conditions }\end{array}$ \\
\hline on-site walks & $\begin{array}{l}\text {-allow one to experience the area directly on site, } \\
\text { which can stimulate discussions and be part of } \\
\text { public consultations }\end{array}$ \\
\hline $\begin{array}{l}\text { workshop meetings with the } \\
\text { use of 3D models }\end{array}$ & $\begin{array}{l}\text { - a method which involves developing solutions } \\
\text { for urban planning and architecture, with the } \\
\text { assistance of a 3D space model }\end{array}$ \\
\hline
\end{tabular}

Figure 1. Own study base on the main forms, tools and instruments of public participation identified in the National Urban Policy 2023 [10].

Workshop meetings involving the use of 3D models are particularly important for this study. This tool should enable "moving" around the urban space, while at the same time allowing the user to clearly see its details. One of the advantages of this method is that one can take into consideration all the elements and features of the space to be arranged and implement comprehensive solutions that respond to all needs. Space imaging with 3D models can also be used in other instruments mentioned in Figure 1-on-site walks, 
participatory budgets, working meetings, surveys and remote voting. However, 3D models can be used both during on-site meetings and indoors, which shows their versatility.

Conventional methods of social participation in spatial planning and management are beginning to evolve into new forms owing to new emerging technologies [11-14]. Information technology offers new potential for citizen participation in urban planning [15]. New technologies allow for a new generation of forms and practice of social participation while providing an interactive, networked environment for making decisions [16]. Among technologies used in social participation, GIS should be mentioned as the most important [17-21]. Social participation also employs online games [15,22-24], social networks and virtual workshops [16,25,26], photo-manipulation [27] and their combinations. Technologies associated with virtual reality-AR and VR-are the latest solutions used in this regard. Virtual reality is increasingly often used as a tool for social participation in the urban space planning process.

Barriers faced by local communities include a low level of specialisation, a low level of understanding of technical and legal language, underdeveloped spatial imagination, simplified perception of reality, poor spatial perception, limited technical skills in computer and mobile device use, etc., all of which can prevent people from becoming involved and make them demonstrate so-called "rational ignorance" [12,28-30]. Therefore, taking part in public consultations is seen as a cost (spending time, absorbing new information, familiarising oneself with the form of participation, learning to use the public participatory application, etc.) and usually brings rather small benefits compared with these costs. Applying visualisation techniques to social participation may eliminate the barrier of lack of professional qualifications, an issue that can thwart AR and VR solutions. Digital 3D visualisation has several advantages compared to conventional presentation methods, especially when complex spatial systems are shown to people without specialist skills [31-34]. Easyto-read 3D models help non-professional users (residents) to understand complex issues related to planned changes in a space [15]. AlKodmany ([27] p. 38, after [35]) points out that "Visualization is the key to effective public participation because it is the only common language to which all participants - technical and non-technical—can relate. Visualization through digital technology provides a common language for all participants". Therefore, computer 3D visualisation techniques can provide an important contribution to the evolution of participatory planning and design. This claim is justified because visualisation is a communication medium that most people utilize on a daily basis [36]. Hanzl [15] points out that it is important to take into consideration two types of spaces-virtual and real. Changes in the real urban environment are preceded by the creation of a consistent vision of what is being planned. Therefore, a 3D model representation in the residents' minds plays a vital role in transforming the real space and can be used in many areas (Figure 2). Virtual reality models allow citizens to understand the proposed changes, encourage them to communicate and lead to understanding of the design-related propositions [31]. Implementation of such an idea allows not only for streamlining the spatial planning process but also for developing open geoinformation societies, which may lead to the creation of "smart cities" in the future [37]. 


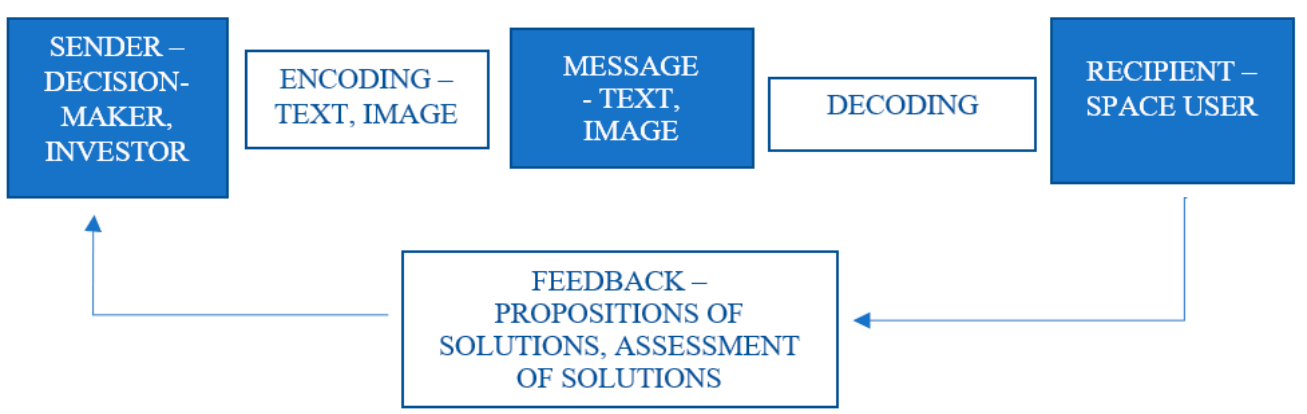

Figure 2. A diagram of communication in public consultations concerning space. Source: Prepared by the author.

\subsection{Communication in a Graphic Form}

Communication is the foundation of humanity. Communication is the transfer of information in an information- and knowledge-based society among individuals, groups and institutions [38]. This term assumes that at least one entity sends a message to at least one recipient (Figure 2). Information encoded by the sender will reach the recipient, who must decode it. For a message to have the desired effect, both entities must use the same coding system and eliminate disturbances effectively.

Information may be transferred between a sender and a recipient in a variety of ways. Depending on the form of information transfer, there are two main forms of communication: verbal and non-verbal. Communication is considered verbal when words-spoken or written-are used to communicate. Non-verbal communication complements oral communication by engaging other senses, such as vision. If information is conveyed by images, it is visual communication. Contemporary forms of communication are often very complex; for example, most forms of visual communication also involve other elements (e.g., text) [39].

Since an act of communication is a social process, methods of communication must be chosen to suit the recipients of information [40]. Due to the great diversity of knowledge and experience among various participants in space planning and management processes, communication in discussions regarding draft documents, plans, design solutions and their later implementations must be clear and transparent; such studies can otherwise be difficult to understand and hermetic because of the language used [41]. Hence, an important role is played by visual communication, which is easier to understand by an unqualified recipient. Visual communication can be described as an act of representation-a process by which the person who creates a message uses visual resources to transfer information, ideas, solutions, assumptions, etc.- - or as communication by proxy [42,43]. Visual communication is described as receiving and transmitting messages by visual means [44]. In an informationbased society, visual communication is one of the main ways of absorbing information and knowledge, and visual communication technology includes images formed by text, graphics and other composite elements [42].

The direct contact that takes place in consultations is the best form of obtaining information, since it allows for rapid modification of the questions asked and the depth of the interview conducted. However, new technologies may provide the only alternative in times of COVID-19 pandemic constraints. Virtual technologies such as mixed reality (MR), virtual reality (VR) and augmented reality (AR) can be an alternative to the classic consultation. All of these concepts fall under extended reality $(X R)$. Extended reality (XR) encompasses all real and virtual combinations of environments and human-machine interactions generated by computer technologies and wearables. In short, XR represents current and future spatial computing technologies that serve to augment the human experience. These include stimulation of the senses of existence (VR technology), stimulation of knowledge acquisition (AR technology) and their combination (MR technology).

Virtual reality is based on a virtually generated world, which is displayed through VR goggles. Augmented reality overlays digital information over elements of the real world; i.e., the basis of augmented reality is the real world, supplemented by digital elements in 
the form of sound, image or object. Most often, based on the view from the camera of a mobile device, new layers of perception of the environment are created. In such a created virtual world, users usually interact with the world via dedicated controllers [45].

The technology that most blurs the boundaries between the digital and real worlds is mixed reality. In this technology, users can interact with both digital and real objects. Users control the digital world with their hands. Images are displayed using mixed reality glasses or goggles.

Tools used in communication related to space planning and management have been modified in line with technological progress (Figure 3), although visual forms have dominated. Virtual reality (VR) is one of the latest tools in visual communication, but its mechanisms and applications distinguish it from other visualisation tools-they are typically used for planned and designed realities that are not yet existent or contain non-existent components [46]. As VR enables people to transfer information from the virtual to the real environment [47] and, in the majority of cases, spatial information is what is transferred between these environments [48], this tool is applicable in a growing range of fields in spatial planning and management.

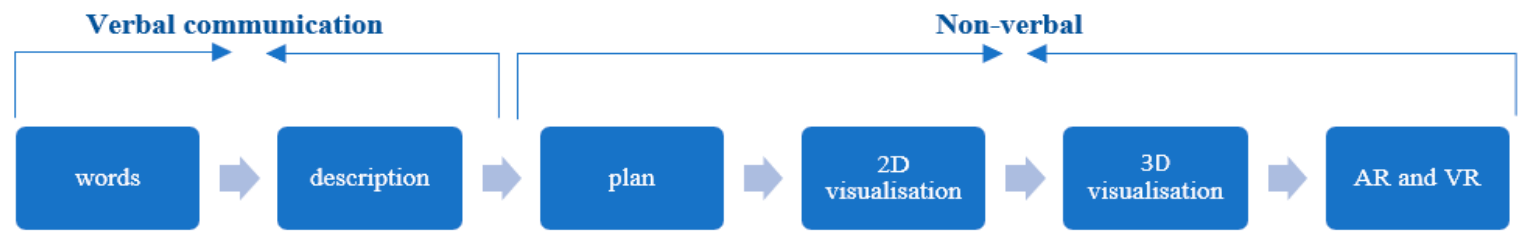

Figure 3. Development of tools for the presentation of planned spatial changes. Source: Prepared by the author.

\subsection{Virtual Reality}

Myron W. Krueger, who developed a responsive environment at the University of Wisconsin-Madison in the 1970s, is regarded as the precursor of virtual reality [49]. His ideas and their implementation have become the prototypes of the current virtual reality. The term "virtual reality" was introduced by Jaron Lanier and Steve Bryson in reference to the work conducted at NASA [50]. They understood virtual reality as a way of using computer technology to create the effect of an interactive 3D world, in which objects give users a feeling of spatial presence [51]. A general operation diagram for virtual reality and its areas of application is shown in Figure 4.
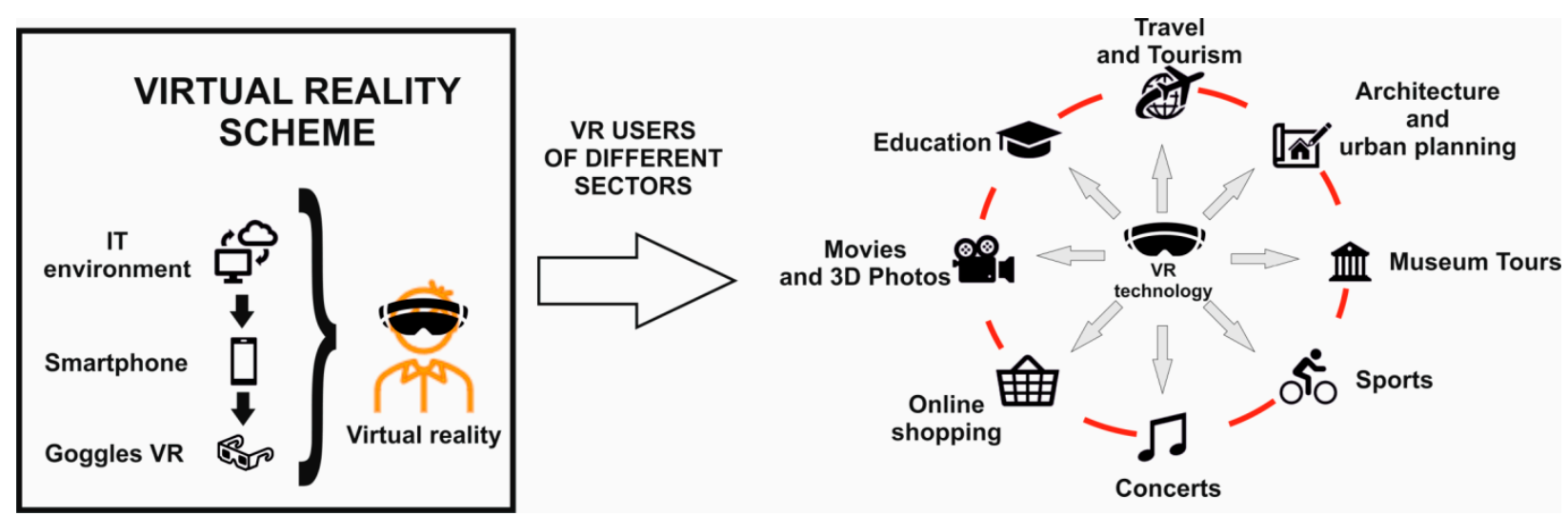

Figure 4. Operational diagram for virtual reality and its areas of application. Source: prepared by the author.

The main goal pursued by VR creators is the development of an artificial world which creates an appearance of reality. Technological progress-mainly an increase in the computing power of devices-and increasingly effective image acquisition algorithms allow for blurring the boundaries between a virtual object and its real counterpart [52]. It is of key importance for the creators of such technology to understand human physiology 
and methods of learning about the surrounding world [53]. A situation must be achieved in which human senses could be deceived using information technology. Implementation of these assumptions results in a head-mounted display (HMD) which allows the user to isolate themselves from the outside world. This procedure takes into account the way the human eye sees and transforms the registered image. Since humans receive stimuli from the outside world with several senses, adding sound effects considerably amplifies the impression. VR creators must bear in mind that a sound message out of synchronization with the image can induce motion sickness in the observer [54].

Response time is another important challenge facing virtual reality. The software must respond immediately after a response from the observer occurs. Otherwise, the user will experience confusion caused by erroneous stimuli received by the senses. In order to optimize the process, devices incorporated into smartphones are used: GNSS antennae, apparati and sensors (e.g., accelerometers, proximity sensor, light sensor, magnetometer, gyroscope, gravitation sensor, compass). Auxiliary equipment has been developed to support the illusion of real life: earpieces, joysticks, special gloves and mats.

The constant developments in VR technology enable interactive citizen participation in decision-making processes concerning urban space. Virtual reality is becoming a new method of simulating changes that take place in real time. With low outlays, it allows for the building of different scenarios of city development. Increasing numbers of experiments are being conducted in this regard. VR technology allows for a better understanding of planning policy when creating a smart city [55] and, at the same time, can be used to increase societal participation in consultations on area management. These needs were identified by Aguilar et al. [56], who proposed a solution involving the use of an interactive tool with a spatial analysis function, supporting the planning and decision-making processes with increasing numbers of consultation participants. Puyana-Romero et al. [57] pointed out that virtual reality can be used on smartphones and Oculus Rift displays for assessment and monitoring of spatial changes in the evaluation of environmental noise in various areas of Naples for future project processes. The findings showed that it allowed for engaging more participants compared to laboratory experiments. Other studies conducted by Patterson et al. [58] showed the opportunities and advantages of using VR in public consultations on landscape planning. The findings showed that respondents who relied only on verbal descriptions visualized spatial solutions that were potentially different from the designers' intentions. Virtual reality also allows for consulting a planning concept. Considerable potential in this regard was confirmed by Howard and Gaborit [59], who used planning solutions designed in a virtual environment for public consultations. The conclusions from the study confirmed that such solutions facilitated and increased public involvement in the planning processes compared to the conventional consultation process.

\section{Study Methodology}

\subsection{Subject Matter of the Study}

The area under analysis is situated in the southeast of the town of Suwałki, in northeast Poland (Figure 5). It lies within the town's administrative borders, several kilometres south of the centre, near the village of Sobolewo (GPS:N 54 $4^{\prime} 29^{\prime \prime}$ E $22^{\circ} 57^{\prime} 42^{\prime \prime}$ ).

This area is administered by Suwalskie Kopalnie Surowców Mineralnych, which previously excavated aggregate at the site. An artificial water reservoir at Sobolewo is situated at the site of a former gravel pit, where gravel was excavated from below the level of the groundwater table. As the minerals are still being excavated, part of the reservoir is included in the technological system of the Sobolewo mine. The other, northern part of the water body is a tourist facility. The water body is fed by many springs in the area. Figure 6 shows the current land development in the area, with a distinctly marked section covered by water. 


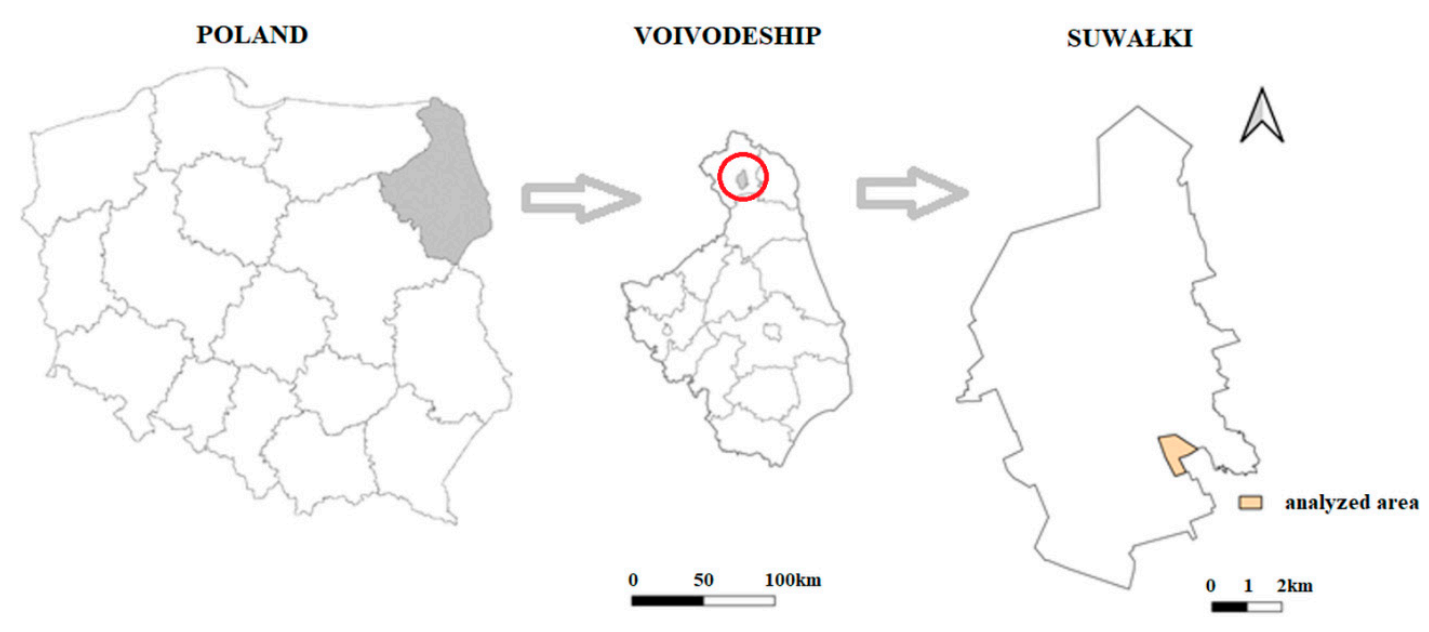

Figure 5. Location of the study area. Source: Prepared by the author.
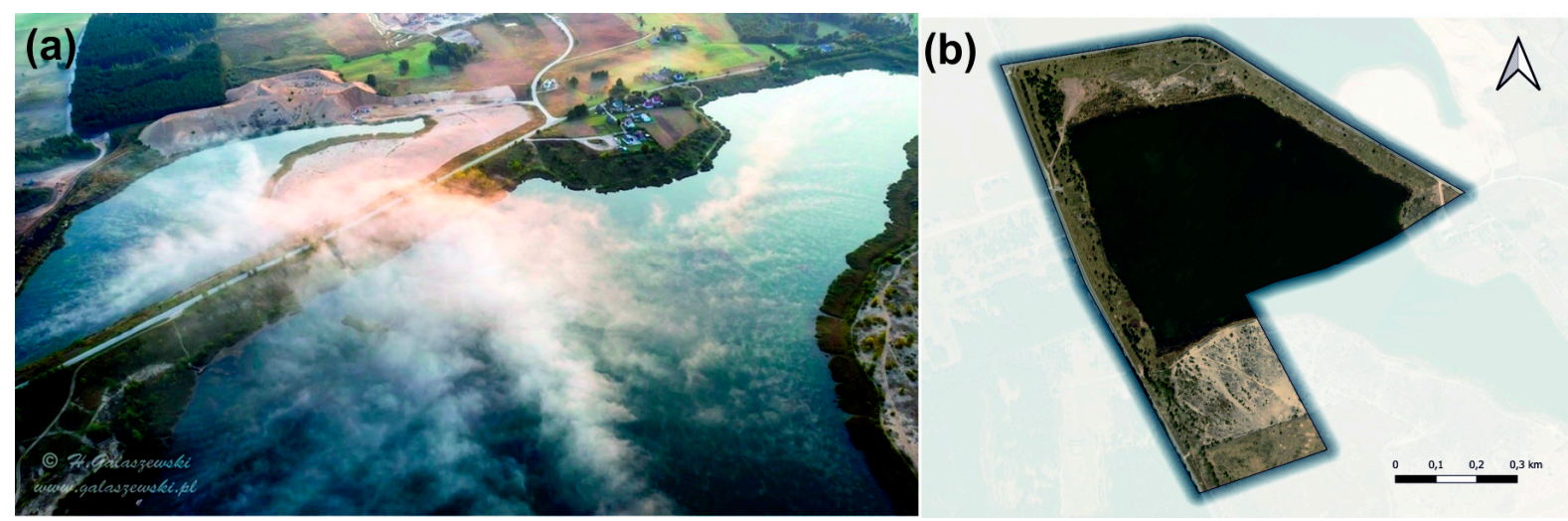

Figure 6. Bird's-eye view of the water reservoir at Sobolewo (a). Source: Gałaszewski H. Current land development in the area under study—orthophoto (b). Source: geoportal.gov.pl.

The area under analysis is covered by a local area development plan, which was passed as a by-law act (Resolution No. XXIV/301/2016 of the Town Council in Suwałki of 26 October 2016 on the local land use plan for the post-gravel pit site-the Sobolewo water reservoir in Suwałki). According to the plan, the area under analysis occupies approx. 67.3 ha of land and is delineated on the drawing (Figure 7). The plan provides for sports and leisure facilities (US-ZP), inland water area (WS) and uncontrolled greenery (ZN).

The plan contains information on future land development in relation to these provisions (Table 1). This information was used in creating a simulation of the post-development area. 


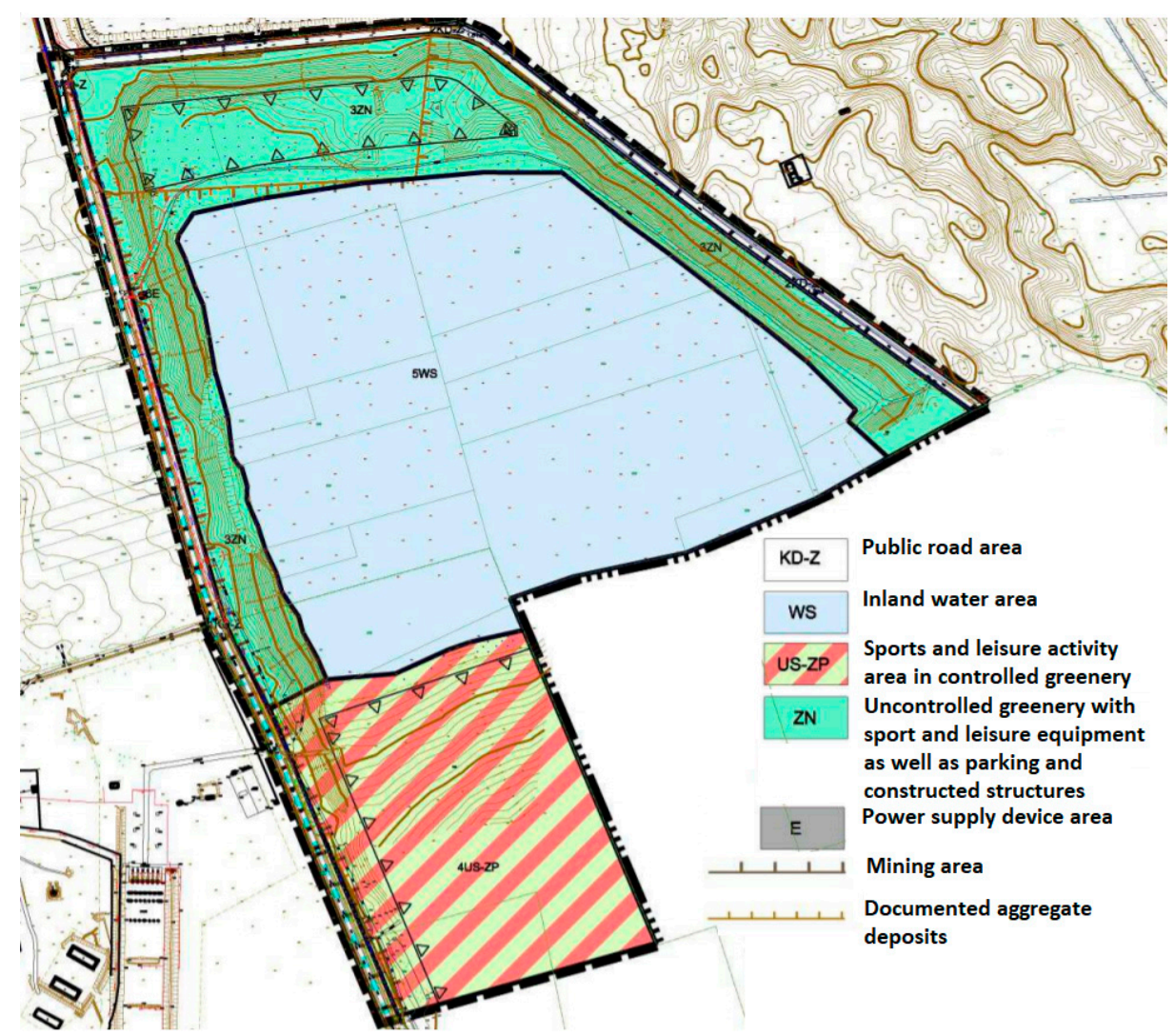

Figure 7. A fragment of the graphic attachment to the local area development plan for the postgravel pit area-Sobolewo reservoir. Source: Local area development plan for the post-gravel pit area-Sobolewo reservoir in Suwałki.

Table 1. Acceptable forms and elements of the area development for the post-gravel pit area-Sobolewo water reservoir in Suwałki.

\section{Purpose of the Land (Function) Forms and Elements of the Area Development}

maintaining existing greenery—-tall, medium and small—and planting new plants; parking places in tall greenery; walking paths with places for rest and equipment for exercise; cycling paths and paths for off-road riding; nature teaching paths, including

$3 \mathrm{ZN}$-areas of uncontrolled greenery (approx. $16.2 \mathrm{ha}$ ) paths as piers continued in 5WS, street furniture, e.g., benches, shelters, observation towers, sites for launching sailing equipment, information boards, lighting posts; and leisure facilities, e.g., fishing boat storage sheds (with an area of up to $150 \mathrm{~m}^{2}$ ), equipment for keeping the area tidy, including environmentally friendly bathrooms and power supply facilities, depending on the power demand, minimal index of biologically active surface at $80 \%$

walking paths with places for rest and equipment for exercise; the paths can have the form of wooden footbridges to protect the land against erosion, places of leisure equipped with shelters with benches, tables and grills, sports fields, tennis courts, golf courses, etc., playgrounds for children, grass area for a bathing beach in 5WS, piers for the beach and sailing equipment, hangars for sailing equipment, lighting of the area, equipment for keeping the area tidy, including environmentally friendly bathrooms, maintenance of the current afforestation and planting of new greenery to achieve a minimum bioactive area index of $75 \%$.

$4 \mathrm{US}-\mathrm{ZP}-$ sports and leisure
facilities in controlled greenery (approx. 12.3 ha)

5WS- the area of the post-excavation site surface water reservoir (approx. $32.5 \mathrm{ha}$ ) municipal bathing site; harbor for water sports equipment; piers for water sports and bathing sites, angling footbridges and piers intended for teaching purposes; necessary adjustment of the coastline and gentle coast slopes to secure them against erosion; observation towers and places for jumping into the water as well as shelters with places for rest, which can be located on piers, service facilities (e.g., cafes) connected with the land via piers 


\subsection{Research Procedure}

The first stage of the research procedure involved preliminary work including an on-site visit to the test area as well as analyses of materials and resources concerning the functions that could be performed (Stage 1). The main goal was to verify the provisions in the local area development plan (see Table 1), which determines the method of land development in accordance with the by-law act. A concept of the land development was prepared in stage 2 based on the acquired information on legal regulations and the natural conditions at the Sobolewo water reservoir, using the map base in the form of a plan drawing, supplemented with information from an orthophoto.

3D models were developed in the SketchUP program, in order to prepare a visualisation of the draft area development design (Stage 3). These models included various elements of street furniture (e.g., benches, chairs, lamps, trees), sport and leisure facilities (e.g., volleyball and basketball pitches with accessories, walking paths, leisure areas, playground with accessories, etc.). Regardless of the design work, a programming environment was prepared for developing an original application presenting the area development concept in augmented reality. This task mainly involved the implementation of the necessary programming libraries and the development of scripts in the C\# language, necessary to compile the application (Stage 4).

Stage 5, which involved creating the 3D virtual world, was one of the most important steps. The 3D models (created at stage 3) were superimposed on the map background prepared at stage 2 , while preserving the uniform system of coordinates for each model in the design and the background map. This mainly concerned preserving the scale and model orientation and defining the beginning of the system of coordinates. Owing to this approach, it was possible to set the model altitudinal orientation and to achieve easy object control in the east-west and north-south directions.

In the next step, the necessary functionalities were defined for the designed application, which allowed for developing a system for moving around the virtual area (Stage 6). This stage involved the first application tests by the users.

The next stage involved informatic work, consisting of validation of the software by performing tests and correcting errors in the code (Stage 7). The work at this stage also involved the choice of target mobile platform (Android).

In the last stage of the work, the application operation manual was prepared, which discussed the recommendations concerning the requirements for mobile devices (e.g., smartphones) and provided guidelines for installing, moving around in and quitting the application (Stage 8). All of this resulted in an application for mobile devices entitled: ArchitektVR. The virtual reality employed in it simulated a realistic environment, in which a user could move around in real-time. The technology was used for both presentations and creative actions. A user must put on special glasses through which they can see the surrounding world (360-degree range), created by the computer, and gain information about the surrounding space. This technology provided many opportunities; it allowed users to look at various angles, to reach out for objects, and to change their shape and parameters. The presence in the created space is achieved through full immersion, which was possible owing to the real-time interaction of the human with the computer. Figure 8 shows a diagram of the work done during the project execution. It also shows the stages of its execution, as discussed above. 


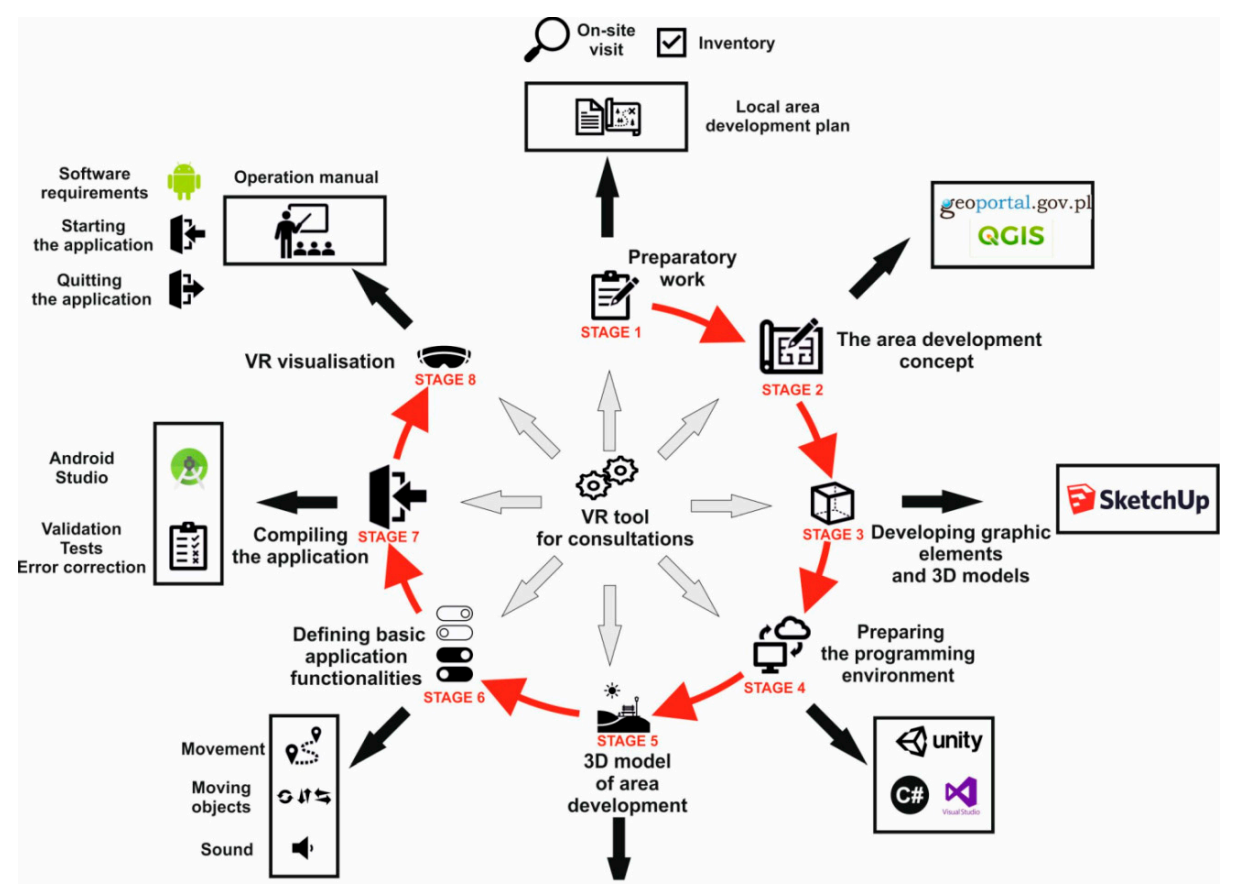

Figure 8. Stages of the execution of the project. Source: Prepared by the author.

Table 2 shows brief characteristics of the main tools used in the project, complementing and expanding the diagram of the project execution stages.

Table 2. Tools used in the project and their characteristics.

A local area development plan is a by-law act, which is
passed as a resolution of the commune council. It contains
detailed guidelines for land development.

Source: prepared by the author.

To define the system requirements, in-depth interviews were conducted with a variety of audiences. This resulted in defining aspects of both the environment and the userfriendliness of the application. This forms a basis for implementing the process into future consultations based on new technologies, such as XR. 


\section{Results}

\subsection{Area Development Plan}

A proposition for development of the exhausted gravel pit-Sobolewo water reservoir was prepared based on the existing graphic attachment to the local area development plan and information from the orthophoto (source Geoportal.gov.pl, accessed on 7 January 2021). After the plan provisions and characteristics of the test area surroundings were taken into account, a proposition for the area development was prepared (Figure 9).

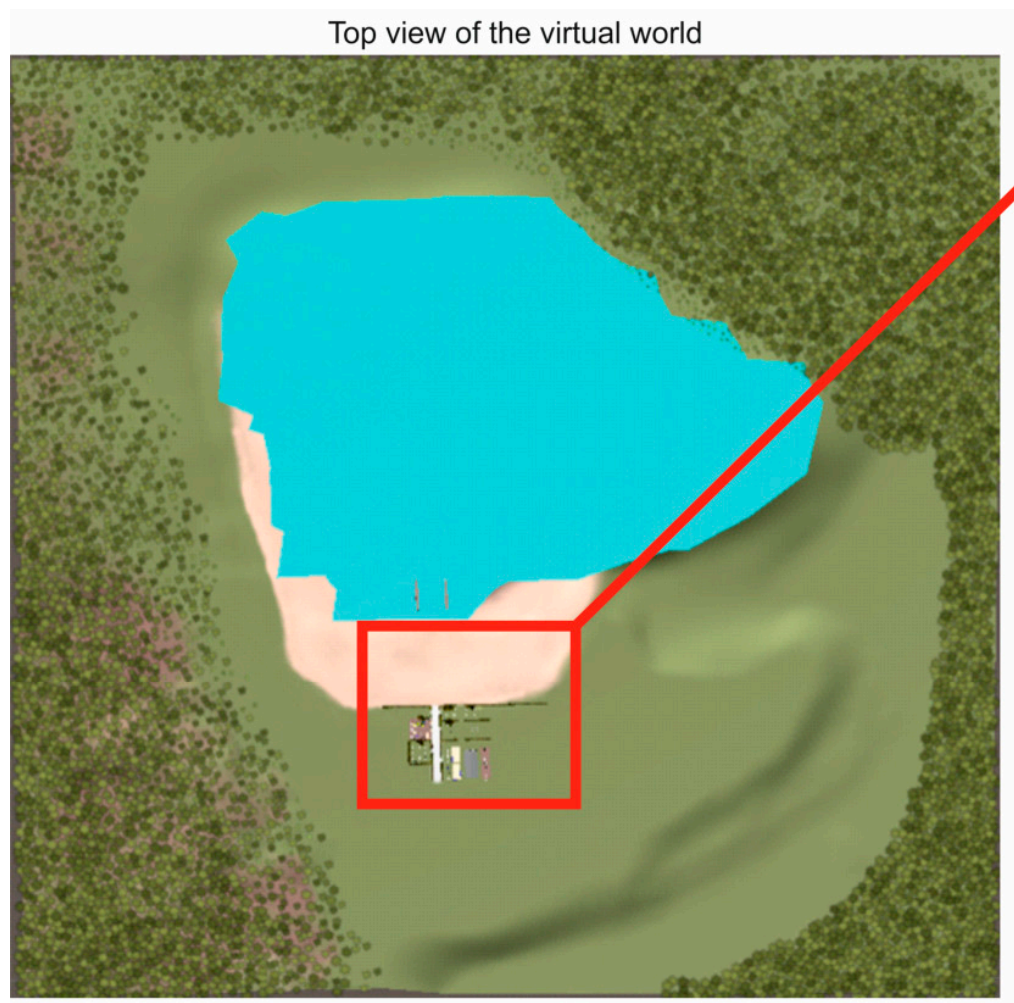

Beach

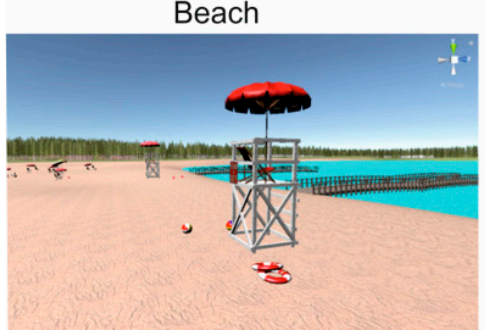

Courtyard gym

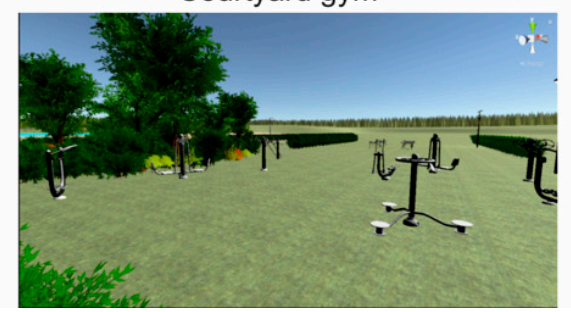

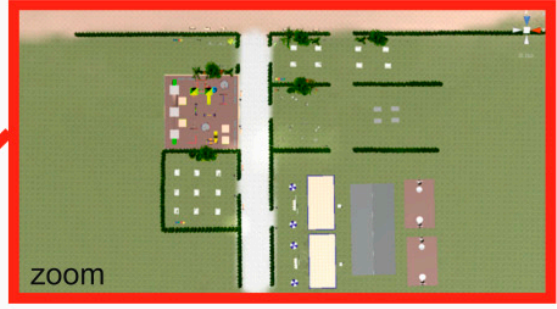

Rest area

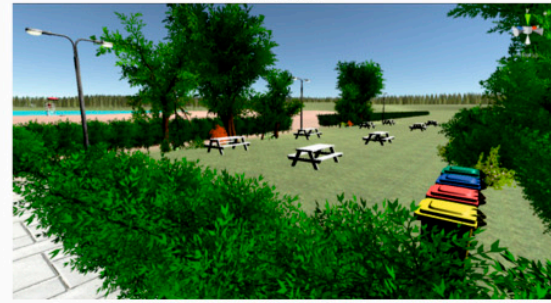

Volleyball courts

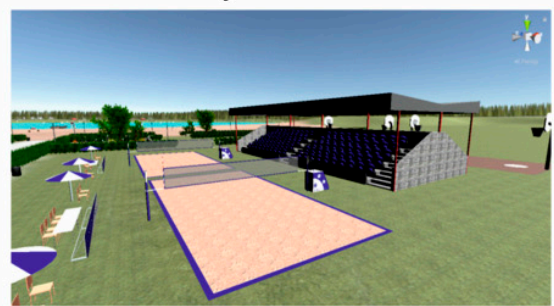

Playground

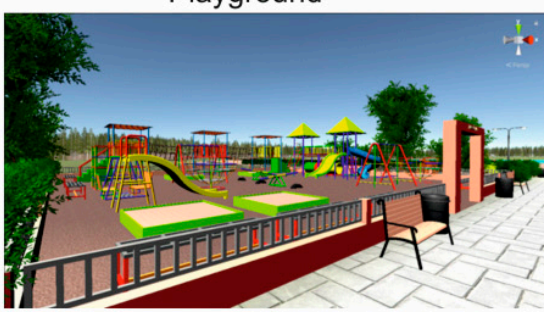

Figure 9. Proposed land development in the test area. Source: prepared by the author.

The background map was opened in the Unity program at a scale of 1:1 and then projected onto the existing land. A development design was prepared for part of the area designated for the US-ZP function (sports and leisure facilities in controlled greenery). 3D models of the development elements were taken from Unity-Asset Store and SketchUp$3 \mathrm{D}$ Warehouse. The following objects were designed in the area: a playground, equipment for open-air exercise, volleyball and basketball pitches with stands, a table for table tennis, walking paths, bicycle parking places and areas with benches and tables for picnics and rest. The design also included benches along the walking paths, lighting to improve visibility and safety after twilight and litter bins for keeping the area tidy. Design solutions were complemented by elements of medium and tall greenery, such as bushes and trees. All of this was complemented by beaches in the southern part of the water reservoir. The area had two piers and two lifeguard towers to ensure the safety of bathers. Additionally, the beach 
had designated areas for playing beach volleyball as well as deckchairs and umbrellas for leisure. The whole proposal provided a coherent urban design solution.

\subsection{ArchitektVR Application}

Android JDK, Android SDK and Android NDK were imported in order to develop the application. Software packs were downloaded from the Android website. The packs enabled developing the area development design in the UNITY environment and creating ArchitektVR, an application that uses VT. The application tests required goggles and a device running Android 4.4 "KitKat" (level API 19). In order to properly configure the mechanisms of movement around the virtual world, the basic laws of physics related to the geometry of movement in the real world had to be defined for programming purposes. Defining the rules enabled the camera (which simulates the observer's eyes) to move in parallel to the area elevation (at the observer's eye level).

Owing to the goggles' monitoring of location with respect to the $\mathrm{X}, \mathrm{Y}$, and $\mathrm{Z}$ aes, elements of interaction and changes in the observer's location could be added in virtual reality (Figure 10).

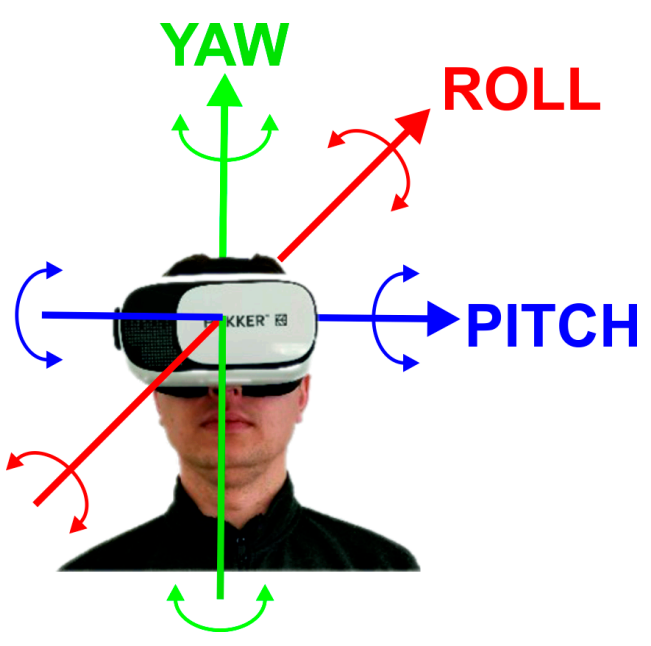

Figure 10. Orientation of VR goggles. Source: prepared by the author.

By changing the position of their head, the user could see various views in the virtual reality. An avatar in the computer world reflected the orientation of the head with goggles in the direction of the gaze in the designed world. Figure 11 shows the mechanism of head movements and the resulting change in the direction of vision in the virtual world (Figures 12 and 13). This change is symbolized by the AVATAR body position (a blue figure in Figure 12).

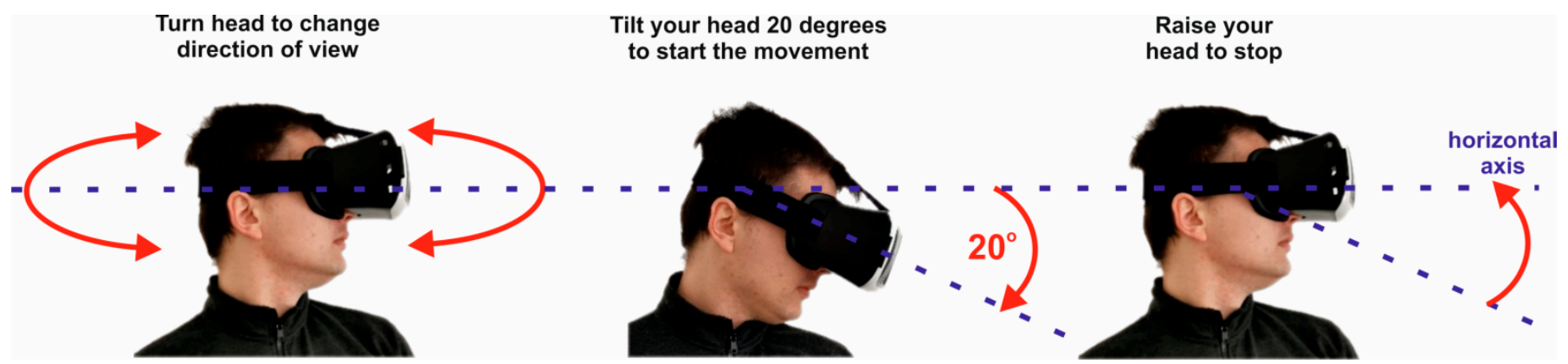

Figure 11. Movement control in the virtual world. Source: prepared by the author. 


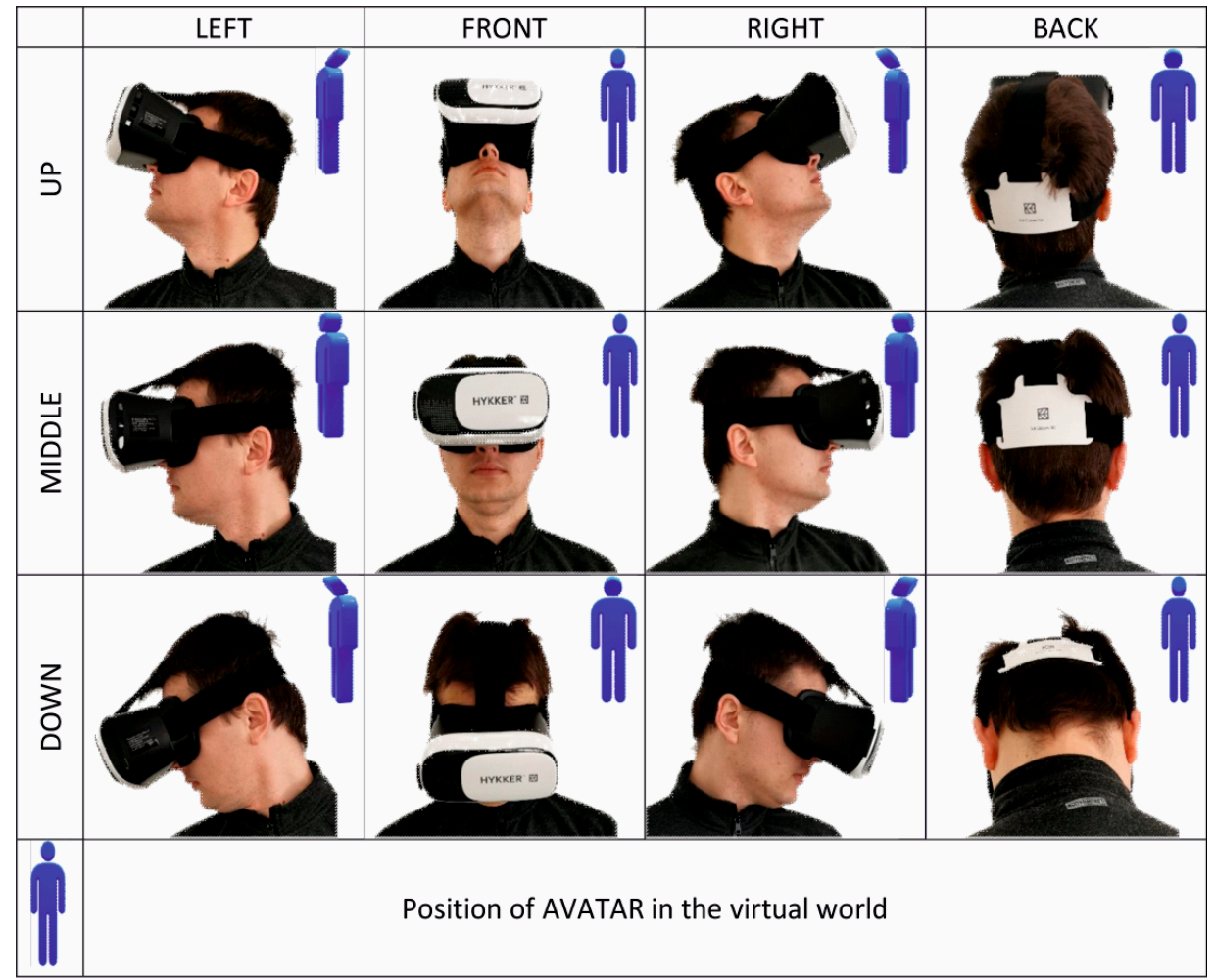

Figure 12. A tour of the virtual design. Source: prepared by the author.

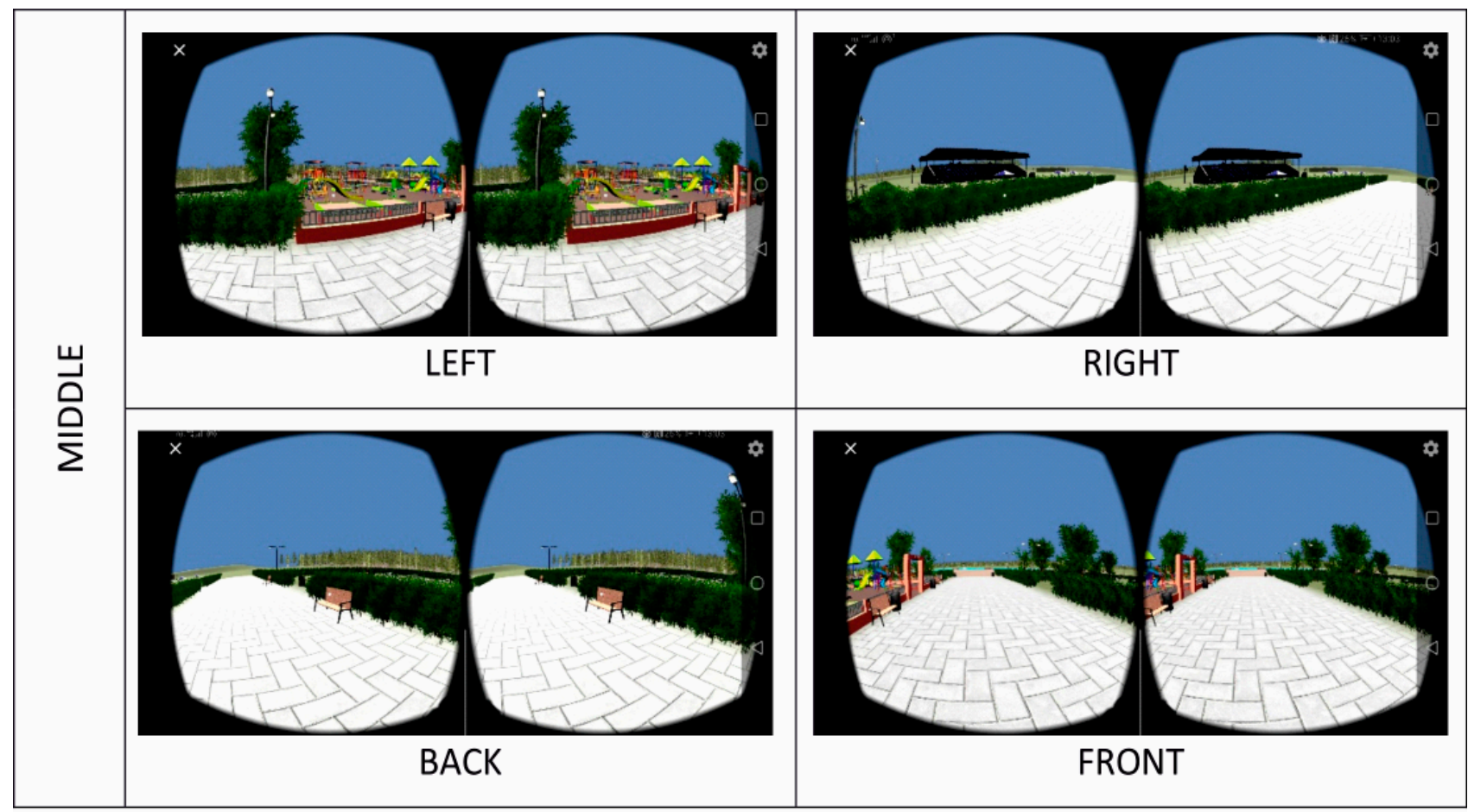

Figure 13. VR views on a mobile device. Source: prepared by the author.

Figure 13 shows a view of a selected location in the virtual world, displayed on a mobile device (smartphone) and visible through goggles. The illustrations show the views displayed in the horizontal plane and covering the full $360^{\circ}$ view (left, front, right, back).

Movement capability was effected by a script in the C\# language, written in Visual Studio. The implemented script (VRLookWalk) contained variables storing the main 
camera, character, angle of vision and speed. After the start button was clicked, the program found objects which stored CharacterController and transferred the user to virtual reality. Users had to lower their heads by $20^{\circ}$ to move forwards. If the angle condition was met, then the character moved by the vector multiplied by velocity. Users had to raise their heads above $20^{\circ}$ to stop moving (Figure 13).

\subsection{Proposed Improvements}

The presented concept of land development was tested on a group of 10 people. Testing was conducted in an in-depth interview format due to lockdown restrictions. Respondents were tested one at a time. The ages of the respondents ranged from 15 to 60 years (five females, five males). Each person represented a different social group defined by level of education, age, gender, level of community involvement and experience in public consultation. Additionally, respondents displayed different levels of map and plan reading skills.

After wearing the goggles and observing the virtual world, respondents answered formalized questions. These questions concerned general impression, readability of presented objects and spatial solutions, evaluation of proportions and spatial interrelations, ease of interpretation of the proposed concept of development and degree of understanding of the provided information. Finally, the respondents answered questions about the validity of implementing VR technology in public consultations. All respondents indicated the need for intuitiveness and ease of use of this type of solution, so that it could be used universally. After answering the formalized questions, respondents made additional comments. The most common suggestions included adding the possibilities of changing one's position and of adding and removing objects and sound from the virtual world. Respondents also indicated that difficulties existed for people who require vision correction by wearing glasses. In such cases, using goggles was difficult. One person also reported problems due to motion sickness. For some of the respondents, this was their first contact with VR. Their impressions were generally very positive. Suggestions for improvements resulting from respondents' comments are presented below.

The application could be expanded by adding interactions with VR controllers. A special menu would allow the user to edit objects, e.g., to change the shape, size, position, structure, color of components, etc., and owing to the measuring function, it would be possible to check the size and distance of individual objects. The location change and distance measurement functions could allow a user to enter another level of design, providing even greater opportunities for project analysis and reducing the probability of conflicts in the space under design.

Moreover, text could be displayed on the created image together with a lector mode to influence the user more effectively, so that the user could understand the author's vision fully and correctly. Owing to this option, it would be possible to provide the user with characteristics of the analysed area by presenting the physico-geographic features of the land (i.e., geographic position, lay of the land, climate and soil conditions, presence of any forms of nature conservation) and a description of each component (e.g., giving dimensions and other technical parameters, the function of each object, etc.). Adding a soundtrack to explain the analysed area would make the impressions even more realistic (e.g., informing about the functions that could be used and parameters of the development elements).

The application could also be developed by adding a special menu to enable active editing of objects present in space-the observer could change the shape, size, position, structure, color of components, etc. The changes would have to be consistent with the local plan, which could be correlated with sound messages (the message would signal a non-conformity with the plan guidelines, which cannot be violated).

These modifications could help to design an area which meets community expectations, and detecting errors at the designing stage would help to avoid undesired effects in the form of social conflicts. 
Additional equipment is needed to use this technology. For use in public consultations, the required amount of equipment should be minimized. In this case, it was necessary to have a smartphone (which are very common) and inexpensive carton glasses (costing approx. PLN 20-approx. EUR 5). These devices were sufficient to review the area development concept in the virtual world and to grasp the spatial relationships in the horizontal and vertical planes. It could make it possible for users to express opinions, to put forward motions and suggestions regarding the proposed solutions, or to correct the design solutions directly in the virtual world.

\section{Summary and Conclusions}

Information societies receive information mainly from computers, which in turn rely mainly on the sense of vision. The aim of the project was to show the opportunities and potential of virtual reality in area development planning and management. Through its use in developing the ArchitektVR application and designing the method of space arrangement in the exhausted gravel pit-Sobolewo water reservoir, the Unity3D graphic engine showed the benefits of virtual reality. Therefore, the assumed objective was accomplished and the study hypothesis was corroborated. The use of virtual reality as a form of communication in area development design helped to show a vision of land use as a 3D image. Visualisation with VR enabled the presentation of various aspects of area development in a clear, easyto-understand form for average users with no specialist qualifications. This was confirmed by preliminary tests conducted by users.

The development of the project management framework, the ArchitektVR application and its capabilities comprise the first part of the project. From a further perspective, these results should enable mass participation of the local community at the stages of preparing the planning documentation and design and implementation of the area development concept. Subsequently, the application will be improved in line with the suggestions and tested on a mass scale by the local community.

After being installed on a mobile device, the application, in combination with 3D goggles, can be a useful tool in public consultations. When evaluating a proposition for a land development concept with virtual reality, one can check the correctness of the design spatial solutions regarding the composition, form, shape, color, utility solutions and, in particular, satisfying the social needs. This technology is the most economic and safest solution in many aspects and areas, especially now that social contacts are limited. The opinions expressed by a local community will help to choose a method of area development which is consistent with its needs and meets all the requirements necessary to be consistent with planning documents.

ArchitektVR may be added to the Google Play shop, an online platform with a huge number of various applications. This will facilitate access to the installation file, and downloading files from this platform is intuitive and fast. Due to rapid technological progress, VR will likely soon be applied in area development planning and management (which is seen in the growth of the VR games market). What is unavailable on a large scale today will soon be in common use-in the same way as smartphones became common, goggles are already becoming common goods.

Certain limitations regarding the common nature of such a form of participation may be a consequence of the participants' age; this especially concerns elderly people. This is associated with the range and availability of devices and the Internet, lack of knowledge of new technologies and activity of the consultation participants. This would be disadvantageous since elderly people have the greatest experience and knowledge of local issues. At the same time, this form of consultation can attract the interest of young people because of the use of modern technologies. Although the use of technology results in certain limitations, it also may attract a new group of users who, until now, were not very interested in active participation in local matters.

An effective and transparent system of communication results in an increase in trust and a better understanding of the issue under consideration. Successful communication 
depends on the form and message quality. In this context, owing to the development of new technologies, new and innovative services can be created which make it easier for recipients to absorb new content. An increase in the computation power of mobile devices has created the possibility for widespread use of augmented reality solutions that blur the boundary between the real and the digital world. The use of VR in public consultations streamlines the communication process. It facilitates the presentation of future changes in a space and allows for the creation of many variants/scenarios of future area development. Participants in consultations receive information about planned changes as visualisations. Effective visualisation of such information can help citizens to make better decisions.

Social participation is a major factor in solving issues related to area development planning. Gamification, fuzzy control and use of virtual reality can make it easier for local and central governments to manage area development planning. Visualisation of future area development solutions enables concerned individuals to assess the potential development of a selected area without a visit-either in the field or to an office. This is of particular importance now during the COVID-19 pandemic and the resulting sanitary restrictions.

Author Contributions: Conceptualization, A.S., R.K. and M.M.; methodology, A.S., R.K. and M.M.; software, R.K. and M.M.; validation, R.K. formal analysis, A.S.; investigation, A.S. and R.K.; resources, M.M.; data curation, R.K.; writing-original draft preparation, A.S. and R.K.; writing-review and editing, A.S. and R.K.; visualization, R.K. and M.M.; supervision, A.S.; project administration, A.S. All authors have read and agreed to the published version of the manuscript.

Funding: This research received no external funding.

Conflicts of Interest: The authors declare no conflict of interest.

\section{References}

1. Leipzig Charter on Sustainable European Cities; Leipzig, Germany, 2020. Available online: https://ec.europa.eu/regional_policy / archive/themes/urban/leipzig_charter.pdf (accessed on 8 September 2021).

2. The New Charter of Athens 2003: The European Council of Town Planners' Vision for Cities in the 21st Century; Alinea Editrice: Firenze, Italy, 2003.

3. Lynch, K. The Image of the City; MIT Press: Cambridge, MA, USA, 1960; Volume 11.

4. Gójska, A.; Kulczyński, P.; Lewenstein, B.; Pogoda, I.; Zielińska, E. Konsultacje Społeczne w Przestrzeni Wielkomiejskiej; Polskie Towarzystwo Socjologiczne: Warszawa, Poland, 2011.

5. Madanipour, A. Whose Public Space? International Case Studies in Urban Design and Development; Routledge: London, UK, 2013.

6. Cisek-Lachowicz, M.; Kichewko, K. Dialog obywatelski w praktyce. Studia Z Polityki Publicznej 2018, 2, 59-72. [CrossRef]

7. Olejniczak, P. Partycypacja społeczna jako podstawa społeczeństwa obywatelskiego. Pr. Nauk. Wałbrzyskiej Wyższej Szkoły Zarzadzania I Przedsiębiorczości 2015, 31, 111-121.

8. Olech, A.; Kaźmierczak, T. Modele partycypacji publicznej. In Partycypacja Publiczna-o Uczestnictwie Obywateli w Zyciu Lokalnej Wspólnoty; Olech, A., Ed.; Fundacja Instytut Spraw Publicznych: Warszawa, Poland, 2011; pp. 100-111.

9. Lauriusz, N. Wprowadzenie do partycypacji społecznej w Polsce. In Partycypacja Społeczna w Polsce. Atlas Dobrych Praktyk; Ćwiklicki, M., Frączek, M., Eds.; Fundacja Gospodarki i Administracji Publicznej: Kraków, Poland, 2013; pp. 26 -38.

10. Krajowa Polityka Miejska 2023; [The National Urban Policy 2023]; The Official Journal of the Republic of Poland "Monitor Polski" item 1235 from December 9; Warszawa, Poland, 2015. Available online: http:/ /www.pte.pl/pliki/2/21/KrajowaPolitykaMiejska.pdf (accessed on 8 September 2021).

11. Downes, M.; Lange, E. What you see is not always what you get: A qualitative, comparative analysis of ex ante visualizations with ex post photography of landscape and architectural projects. Landsc. Urban Plan. 2015, 142, 136-146. [CrossRef]

12. Krek, A. Rational ignorance of the citizens in public participatory planning. In Proceedings of the 10th Symposium on Informationand Communication Technologies (ICT) in Urban Planning and Spatial Development and Impacts of ICT on Physical Space, CORP, Vienna, Austria, 22-25 February 2005; Volume 5, p. 420.

13. Danahy, J.W. Technology for dynamic viewing and peripheral vision in landscape visualization. Landsc. Urban Plan. 2001, 54, 127-138. [CrossRef]

14. Lange, E. The limits of realism: Perceptions of virtual landscapes. Landsc. Urban Plan. 2001, 54, 163-182. [CrossRef]

15. Hanzl, M. Information technology as a tool for public participation in urban planning: A review of experiments and potentials. Des. Stud. 2007, 28, 289-307. [CrossRef]

16. Evans-Cowley, J.; Hollander, J. The new generation of public participation: Internet-based participation tools. Plan. Pract. Res. 2010, 25, 397-408. [CrossRef] 
17. Brown, G. Public participation GIS (PPGIS) for regional and environmental planning: Reflections on a decade of empirical research. J. Urban Reg. Inf. Syst. Assoc. 2012, 25, 7-18.

18. Bugs, G.; Granell, C.; Fonts, O.; Huerta, J.; Painho, M. An assessment of Public Participation GIS and Web 2.0 technologies in urban planning practice in Canela, Brazil. Cities 2010, 27, 172-181. [CrossRef]

19. Simao, A.; Densham, P.J.; Haklay, M.M. Web-based GIS for collaborative planning and public participation: An application to the strategic planning of wind farm sites. J. Environ. Manag. 2009, 90, 2027-2040. [CrossRef]

20. Ceccato, V.A.; Snickars, F. Adapting GIS technology to the needs of local planning. Environ. Plan. B Plan. Des. 2000, 27, 923-937. [CrossRef]

21. Sieber, R. Public participation geographic information systems: A literature review and framework. Ann. Assoc. Am. Geogr. 2006, 96, 491-507. [CrossRef]

22. Aguilar, R.; Flacke, J.; Pfeffer, K. Towards supporting collaborative spatial planning: Conceptualization of a map table tool through user stories. ISPRS Int. J. Geo. Inf. 2020, 9, 29. [CrossRef]

23. Ampatzidou, C.; Constantinescu, T.; Berger, M.; Jauschneg, M.; Gugerell, K.; Devisch, O. All work and no play? Facilitating serious games and gamified applications in participatory urban planning and governance. Urban Plan. 2018, 3, 34-46. [CrossRef]

24. Poplin, A. Playful public participation in urban planning: A case study for online serious games. Comput. Environ. Urban Syst. 2012, 36, 195-206. [CrossRef]

25. Campagna, M.; Floris, R.; Massa, P.; Girsheva, A.; Ivanov, K. The Role of Social Media Geographic Information (SMGI) in Spatial Planning. In Planning Support Systems and Smart Cities; Lecture Notes in Geoinformation and Cartography; Geertman, S., Ferreira, J., Jr., Goodspeed, R., Stillwell, J., Eds.; Springer: Cham, Switzerlands, 2015. [CrossRef]

26. Al-Kodmany, K. Using visualization techniques for enhancing public participation in planning and design: Process, implementation, and evaluation. Landsc. Urban Plan. 1999, 45, 37-45. [CrossRef]

27. Rzeszewski, M.; Kotus, J. Usability and usefulness of internet mapping platforms in participatory spatial planning. Appl. Geogr. 2019, 103, 56-69. [CrossRef]

28. Natarajan, L. Socio-spatial learning: A case study of community knowledge in participatory spatial planning. Prog. Plan. 2017, 111, 1-23. [CrossRef]

29. Rinner, C.; Bird, M. Evaluating community engagement through argumentation maps-A public participation GIS case study. Environ. Plan. B Plan. Des. 2009, 36, 588-601. [CrossRef]

30. Stauskis, G. Development of methods and practices of virtual reality as a tool for participatory urban planning: A case study of Vilnius City as an example for improving environmental, social and energy sustainability. Energy Sustain. Soc. 2014, 4, 1-13. [CrossRef]

31. Van den Brink, A.; Van Lammeren, R.; Van de Velde, R.; Silke, D.Ã. Imaging the Future: Geo-Visualisation for Participatory Spatial Planning in Europe; Wageningen Academic Publishers: Wageningen, The Netherlands, 2017; Volume 3.

32. Bishop, I.D. Visualization for participation: The advantages of real-time? In Trends in Real-Time Landscape Visualization and Participation; Buhmann, E., Paar, P., Bishop, I.D., Lange, E., Eds.; Wichmann: Dessau, Germany, 2005; pp. 1-15.

33. Lange, E.; Hehl-Lange, S.; Mambretti, I. Assessment of Urban Green Space Qualities Using 3D Visualization Tools. In The Real and Virtual Worlds of Spatial Planning; Koll-Schretzenmayr, M., Keiner, M., Nussbaumer, G., Eds.; Springer: Berlin, Heidelberg, 2004. [CrossRef]

34. King, S.; Conley, M.; Latimer, B.; Ferrari, D. Co-Design: A Process of Design Participation; Van Nostrand Reinhold: New York, NY, USA, 1989.

35. Pettit, C.J.; Raymond, C.M.; Bryan, B.A.; Lewis, H. Identifying strengths and weaknesses of landscape visualisation for effective communication of future alternatives. Landsc. Urban Plan. 2011, 100, 231-241. [CrossRef]

36. Gnat, M.; Leszek, K.; Olszewski, R. The Use of Geoinformation Technology, Augmented Reality and Gamification in the Urban Modeling Process. In Computational Science and Its Applications-ICCSA 2016; Gervasi, O., Murgante, S., Misra, S., Rocha, A.M.A.C., Torre, C.M., Taniar, D., Apduhan, B.O., Stankova, E., Wang, S., Eds.; ICCSA 2016. Lecture Notes in Computer Science; Springer: Cham, Switzerland, 2016; Volume 9787. [CrossRef]

37. Cicha, K. Komunikacja wizualna-humanistyczne oblicze informatyki? Studia Ekon. 2017, 317, 42-53.

38. Aguilar, J.; Díaz, F.; Altamiranda, J.; Cordero, J.; Chavez, D.; Gutierrez, J. Metropolis: Emergence in a Serious Game to Enhance the Participation in Smart City Urban Planning. J. Knowl. Econ. 2020, 1-24. [CrossRef]

39. Pereira, G.C.; Rocha, M.C.F.; Poplin, A. e-Participation: Social Media and the Public Space. In Computational Science and Its Applications-ICCSA 2012; Murgante, B., Gervasi, O., Misra, S., Nedjah, N., Rocha, A.M.A.C., Taniar, D., Apduhan, B.O., Eds.; Lecture Notes in Computer Science; Springer: Berlin/Heidelberg, Germany, 2012; Volume 7333. [CrossRef]

40. Müller, M.G. What is visual communication? Past and future of an emerging field of communication research. Stud. Commun. Sci. 2007, 7, 7-34.

41. Rodríguez Estrada, F.C.; Davis, L.S. Improving visual communication of science through the incorporation of graphic design theories and practices into science communication. Sci. Commun. 2015, 37, 140-148. [CrossRef]

42. Zimnicka, A. Komunikacja graficzna w strategiach rozwoju województwa. Przestrz. I Forma 2011, 16, 165-176.

43. Jiang, B.; Qing, H. Research on the Innovation of Multimedia Technology and Visual Communication Technology. J. Phys. Conf. Ser. 2020, 1693. [CrossRef] 
44. Kukkonen, K. The map, the mirror and the simulacrum: Visual communication and the question of power. In Images in Use: Towards the Critical Analysis of Visual Communication; Stocchetti, M., Kukkonen, K., Eds.; John Benjamins Publishing: Amsterdam, The Netherlands, 2011; pp. 55-67.

45. Jerald, J. The VR Book: Human-Centered Design for Virtual Reality; Morgan \& Claypool: San Rafael, CA, USA, 2015.

46. Racine, N. Visual Communication: Understanding Maps, Charts, Diagrams, and Schematics; Learning Express: New York, NY, USA, 2002.

47. Portman, M.E.; Natapov, A.; Fisher-Gewirtzman, D. To go where no man has gone before: Virtual reality in architecture, landscape architecture and environmental planning. Comput. Environ. Urban Syst. 2015, 54, 376-384. [CrossRef]

48. Wilson, P.N.; Foreman, N.; Tlauka, M. Transfer of spatial information from a virtual to a real environment. Hum. Factors 1997, 39, 526-531. [CrossRef]

49. Péruch, P.; Belingard, L.; Thinus-Blanc, C. Transfer of spatial knowledge from virtual to real environments. In Spatial Cognition II: Integrating Abstract Theories, Empirical Studies, Formal Methods, and Practical Applications; Freksa, C., Brauer, W., Habel, C., Wender, K.F., Eds.; Springer: Berlin/Heidelberg, Germany, 2000; pp. 253-264.

50. Krueger, M.W. Responsive environments. In Proceedings of the National Computer Conference, Dallas, TX, USA, 13-16 June 1977; pp. 423-433.

51. Lanier, J. Virtual reality: The promise of the future. Interact. Learn. Int. 1992, 8, 275-279.

52. Burdea, G.C.; Coiffet, P. Virtual Reality Technology; John Wiley \& Sons: New York, NY, USA, 2003.

53. Greengard, S. Virtual Reality; MIT Press: Cambridge, MA, USA, 2019.

54. Harris, B.J. The History of the Future: Oculus, Facebook, and the Revolution that Swept Virtual Reality; HarperCollins Publisher: London, UK, 2019.

55. Munafo, J.; Diedrick, M.; Stoffregen, T.A. The virtual reality head-mounted display Oculus Rift induces motion sickness and is sexist in its effects. Exp. Brain Res. 2017, 235, 889-901. [CrossRef] [PubMed]

56. Jamei, E.; Mortimer, M.; Seyedmahmoudian, M.; Horan, B.; Stojcevski, A. Investigating the role of virtual reality in planning for sustainable smart cities. Sustainability 2017, 9, 2006. [CrossRef]

57. Puyana-Romero, V.; Lopez-Segura, L.S.; Maffei, L.; Hernández-Molina, R.; Masullo, M. Interactive soundscapes: 360-video based immersive virtual reality in a tool for the participatory acoustic environment evaluation of urban areas. Acta Acust. United Acust. 2017, 103, 574-588. [CrossRef]

58. Patterson, Z.; Darbani, J.M.; Rezaei, A.; Zacharias, J.; Yazdizadeh, A. Comparing text-only and virtual reality discrete choice experiments of neighbourhood choice. Landsc. Urban Plan. 2017, 157, 63-74. [CrossRef]

59. Howard, T.L.; Gaborit, N. Using virtual environment technology to improve public participation in urban planning process. J. Urban. Plan. Dev. 2007, 133, 233-241. [CrossRef] 